\title{
Making the Business Case for Environmental Sustainability
}

\section{Citation}

Henderson, Rebecca. "Making the Business Case for Environmental Sustainability." Harvard Business School Working Paper, No. 15-068, February 2015.

\section{Permanent link}

http://nrs.harvard.edu/urn-3:HUL.InstRepos:14369097

\section{Terms of Use}

This article was downloaded from Harvard University's DASH repository, and is made available under the terms and conditions applicable to Open Access Policy Articles, as set forth at http:// nrs.harvard.edu/urn-3:HUL.InstRepos:dash.current.terms-of-use\#OAP

\section{Share Your Story}

The Harvard community has made this article openly available.

Please share how this access benefits you. Submit a story.

\section{Accessibility}


H A R VAR D

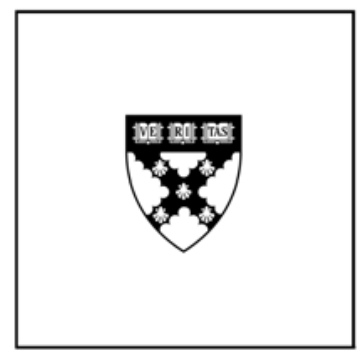

\title{
Making the Business Case for Environmental Sustainability
}

\author{
Rebecca Henderson
}

\section{Working Paper}

15-068

February 19, 2015 


\section{Making the Business Case for Environmental Sustainability}

Rebecca Henderson, Harvard Business School

September 30, 2014

Can a business case be made for acting sustainably? This is a difficult question to answer precisely, largely because there is no generally accepted definition of the term "sustainability". Is it acting sustainably to protect the human rights of the firm's workforce? To invest in education in local communities? To switch to renewable power? All of these actions might improve social welfare, and some of them might improve profitability but they are very different, and the business case for each of them is similarly likely to look quite different. Here I begin to explore the issue by focusing on a more limited question, namely whether a business case be made for acting in an environmentally sustainable way, which I define as acting in any way that reduce a firm's environmental footprint.

An accumulating body of research suggests that reducing the environmental impact of the private sector is likely to have significant social returns (Stern, 2008; Jorgenson et al, 2014). Reducing the use of fossil fuel based energy and hence of $\mathrm{CO} 2$ emissions reduces the risk of climate change, for example, and using fewer raw materials and adopting more sustainable fishing or farming practices reduces pressure on the world's eco-systems. However it is not immediately clear that these kinds of actions are likely to yield significant private returns. The risks of climate change or of eco-system destruction are classic "externalities" in that their costs accrue to the broader society and not to a particular firm, so that in a competitive market firms that invest to reduce their environmental footprint - by, for example, reducing the amount of waste they generate, using renewable energy or investing in more efficient equipment - are running the risk of putting themselves at a competitive disadvantage if these actions simply contribute to the public good.

The substantial scholarly literature that has attempted to measure the relationship between economic returns and sustainable behavior underlines this tension, finding that at the very least the relationship between addressing environmental issues and immediate financial returns is a complex one. Margolis and Walsh, (2003), for example, in one of the best summaries of this 
literature, find no evidence that embracing sustainability increases profitability, and although some recent papers suggest that these kinds of investments can increase returns (See, for example, Eccles et. al, 2013), other work continues to find no correlation between financial returns and investments in sustainability. Figure (1), for example, maps the relationship between a comprehensive set of social and environmental indicators and financial performance over the previous two years for 1,100 CEOs (Hansen et al, 2013). It suggests - and the authors confirm that the correlation between them is very close to zero.

Figure 1 Hansen/Ibarra about here

Does this evidence imply that the business case for investing in environmental sustainability cannot be made? Certainly some observers has suggested that this is the case, arguing that the public sector is much better equipped to handle environmental problems than the private, and that at best those private firms who invest in environmental sustainability (hereafter simply "sustainability") are engaged in sophisticated green washing (Stavins, 2011).

In this chapter, however, I argue that this conclusion is fundamentally mistaken. The push to transform our economy from one based on the premise that natural resources are inexhaustible and that waste can be freely disposed of to one that acknowledges natural limits and actively minimizes waste is fundamentally disruptive, requiring firms to make sustainability a central strategic concern and to change their operations, strategies and organizational processes in fundamental ways. As such, it will require business leaders to actively manage the tension between "exploitation", or the need to continue to exploit current ways of doing things and "exploration", and the need to invest in preparing for a major shift. One of the reasons that these kinds of discontinuities challenge the status quo is that the investments required to prepare for the future are rarely immediately profitable (Bresnahan, 2012; Christensen, 1997; Tushman and Romanelli, 1985). The business case for making them cannot rely on immediate, short term returns. Instead it rests on a sophisticated understanding of the risks entailed in doing nothing and on the opportunities inherent in moving early to prepare for a range of plausible futures. 
It is thus not surprising that cross sectional analyses of the relationship between financial returns and investments in sustainability do not - as yet - yield any easy answers. In a number of industries - particularly in energy, the built environment, agriculture and consumer goods investments to increase environmental sustainability have compelling economics on short time frames. But in many sectors these kinds of investments are best thought of as experiments, strategic hedges, or plausible bets against a coming world, rather than as investments that are likely to shift overall corporate performance today. The recognition that this is the case has significant implications for not only how leaders should make the case for change, but also for the ways in which the strategy making process should be managed and for the ways in which investments in sustainability should be organized.

To make this case I begin by focusing on those instances in which investing in sustainability already yields immediate, predictable returns. Building on a range of examples and the typology developed in Esty and Winston's "Green to Gold” (2006) I suggest that three business models have emerged to date as particularly powerful ways to make money from acting sustainably: forestalling risk, increasing operational efficiency and selling to the environmental niche. I then draw on a scenario technique developed by Peter Schwartz (1996) to highlight the way in which increasing environmental degradation is likely to create the conditions under which these models will become increasingly compelling across a wide range of industries.

I argue that in many industries increasing environmental pressures may lead to major changes in the competitive context - including significant shifts in the nature of consumer demand, in the regulatory environment and in the availability of cost effective environmentally friendly technology. I suggest that these uncertainties mean that most firms face (at least) four possible futures, in three of which investing in sustainability is likely to be a significant source of competitive advantage. Using the examples of Unilever, M\&S, Nissan, Duke and BP, I suggest that leading firms are already using this perspective to make the case for investing in sustainability, despite the fact that these kinds of investments may not be immediately profitable in a "business as usual" scenario. I suggest that the key to building a business case in these circumstances is to make investments that are robust -- to make investments that are at least 
marginally profitable in today's world, but that simultaneously position the firm for significant competitive advantage as and when the competitive context changes.

I close by suggesting that this perspective has important implications for the effective leadership of sustainable change, since it implies that investing in sustainability requires the explicit recognition that the firm faces a multiplicity of possible futures. Leading effectively in the face of this kind of uncertainty requires both challenging the conventional strategy process and the ability to hold the organizational tension inherent in investing in any "exploratory" project (March, 1991). Rather than insisting that environmental investments are certain to yield returns, leading effective change requires senior leaders to create both organizational and strategic flexibility inside the firm, and to create the capability to be both efficient and sustainable. These are precisely the kinds of capabilities highlighted so effectively in this book (See for example, Silvestri and Gulati, Kanter, Tushman, O’Reilly, and Harreld, Ancona et al, and Edmondson et al).

Investing in Environmental Sustainability: the Case for Current Action

A lively practitioner orientated literature - including "Green to Gold" (Esty and Winston, 2006), "Shared Value" (Porter and Kremer, 2011), “The Resource Revolution" (Hecht, 2014) and "The Big Pivot" (Winston, 2014) argues that the environmental crisis is creating very significant opportunities for the private sector. One particularly compelling example of this stream of work is the "McKinsey cost curve" - an analysis by McKinsey, the global consulting firm, that suggests that nearly half of all of the currently available opportunities for reducing emissions of green-house gases are NPV positive, or economically viable right now (Figure 2).

Figure 2: McKinsey cost curve about here

Indeed many firms claim to be actively investing in becoming more environmentally sustainable. For example nearly 6,000 report issue some form of sustainability report under the GRI, the 
Global Reporting Initiative ${ }^{1}$ "Sustainability" is a broad term, and many of these firms may be focused more on social and governance issues than on environmental concerns, but nonetheless there is increasingly compelling evidence that environmental sustainability is big business. A recent front page article in the New York Times suggested that "Industry Awakens to the Threat of Climate Change" and for many firms investments in sustainability appear to have yielded immediate returns ${ }^{2}$ Three business models have emerged as particularly promising: forestalling risk, increasing operational efficiency and selling to the environmental niche. ${ }^{3}$

\section{Forestalling Risk: Preventing Brand Damage and/or preserving "License to Operate"}

The combination of an increasingly global media, the widespread penetration of social networks and an increasingly concerned consumer base has led many firms with large, consumer facing brands to invest aggressively in sustainable business practices to forestall potential brand damage. Similarly firms facing tight regulatory environments or potentially hostile communities have also invested heavily in the attempt to head off potential regulation and/or the loss of the firm's "license to operate".

For example allegations that Nike's factories were polluting local water ways were a major factor in persuading the firm to invest heavily in sustainability. Nike now employs more than 135 people in its sustainability group, and has publicly committed to a range of aggressive targets in the area. Similarly some years ago Greenpeace accused both McDonalds and Kimberly Clark of contributing to deforestation (of the Amazon and of old growth forest in the US, respectively). In response McDonalds took the lead in spearheading industry wide efforts to preserve the Amazon, and both firms have committed to sourcing policies that promise to steadily increase the environmental sustainability of their supply chains. ${ }^{4}$

Coca Cola's engagement with the question of water scarcity is another striking example. Nearly ten years ago Coca Cola - whose brand is estimated to be worth more than $\$ 77 \mathrm{bn}$, nearly half of

\footnotetext{
${ }^{1}$ http://database.globalreporting.org/

${ }^{2} \mathrm{http}: / /$ www.nytimes.com/2014/01/24/science/earth/threat-to-bottom-line-spurs-action-on-climate.html?_r=0

${ }^{3}$ How does this typology relate to $G$ to $G$ typology?

${ }^{4}$ http://www.aboutmcdonalds.com/mcd/sustainability/library/policies_programs/sustainable_supply_chain/Rainf orest_Conservation.html
} 
the firm's entire capitalization -- was accused by Indian activists of depleting local water suppliers and was the target of widespread local action and global criticism as a result. ${ }^{5}$ While the firm disputed the accuracy of the underlying charges it has since launched a major effort focused on water, announcing a commitment to become "water neutral". 6

Similar dynamics have led a number of firms - particularly in the chemical and in the extractive industries - to invest in reducing their environmental impact in an attempt to preclude community pressure and/or additional regulation. The evidence is mixed as to whether such 'self-regulation' is as effective as more standard regulation in reducing pollution (Toffel and Short, 2011), but there is compelling evidence that the chemical industry's extensive investments in both waste reduction has more than covered its costs through the delivery of significant improvements in operational efficiency (Hoffman, 2002).

\section{Increasing operational efficiency}

As the introduction to this volume suggested, one of the most immediate impacts of the environmental crises we face has been increasing input costs. For example figure 3 shows the recent increase in commodity prices.

\section{Figure 3 Commodity prices}

As a result many firms are finding that there is a great deal of money to be made in increasing the efficiency with which resources are used. As Figure (1) suggested, this dynamic is particularly salient in the case of energy, where both anecdotal evidence and a number of careful comparative studies suggest that a compelling business case for increasing energy efficiency exists in many contexts. For example, a recent National Academies study conducted on behalf of the Department of Defense concluded that using LEED-Silver or equivalent standards in the design and construction of new buildings increased the costs of initial construction between 0 $8 \%$, but that since construction costs are typically only $5-10 \%$ of total life cycle costs, building "green" or "high performance" buildings increased total costs by less than $1 \%$ while reducing

\footnotetext{
${ }^{5} \mathrm{http}: / /$ www.nytimes.com/2008/01/16/business/16 coke.html?ref=asia\&_r=0

${ }^{6} \mathrm{http} / / / \mathrm{www} . c o c a-c o l a c o m p a n y . c o m /$ stories/our-water-conservation-goal
} 
energy costs by between 5 and $30 \%$ and water use by $8-11 \%$ over the life of the building. The commission recommended that all new DOD buildings or major renovations use these standards. $^{7}$

The widespread recognition of this opportunity has fueled the growth of hundreds of new firms. For example, Johnson Controls, one of the largest players in the space, had 2012 revenues of over \$14bn in their energy efficiency business, while Schneider Electric, a $€ 23$ bn global energy giant, recently repositioned itself as the "only global specialist in energy management" and claimed that more than $35 \%$ of its revenues were derived from its integrated solutions business. Similarly an increasing fraction of new construction is being built with an eye to increased energy efficiency and heavy equipment manufacturers across a range of industries have introduced energy efficient products including aerospace engines (GE, Rolls Royce) and compressors (Ingersoll Rand, United Technology).

Many firms have also reported significant savings from individual efforts to reduce energy. For example KKR claims that the imposition of a systematic process of energy and water reduction across their portfolio companies has yielded returns of at least $\$ 150 \mathrm{~m}$ a year for each of the last five years (Eccles, Serafeim and Clay, 2012), while between 1990 and 2012 IBM reduced electricity consumption by 6.1 billion $\mathrm{kWh}$, saving $\$ 477$ million through energy conservation alone. ${ }^{8}$. Maersk, the world's largest container shipping company, forecasting that the cost of fuel was likely to rise from $\$ 250 /$ ton in 2008 to $\$ 700 /$ ton by 2020 , committed to an aggressive program of energy efficiency, introducing "slow steaming" by its ships and reducing fuel use by $7 \%$ between 2009 and 2012 (Reinhardt, 2012). One report from the UN Foundation estimated that an investment of \$US3.2 trillion worldwide in energy conservation would avoid new supply investments of $\$ 3$ trillion and would pay for itself within three to five years. ${ }^{9}$

Similarly technologies that enable reductions in water use are opening up new markets. For example Jain Irrigation, an Indian firm specializing in "micro-irrigation” techniques, saw

\footnotetext{
${ }^{7}$ National Research Council. Energy-Efficiency Standards and Green Building Certification Systems Used by the Department of Defense for Military Construction and Major Renovations . Washington, DC: The National Academies Press, 2013.

${ }^{8}$ http://www.ibm.com/ibm/environment/climate/

${ }^{9}$ http://www.globalproblems-globalsolutions-files.org/unf_website/PDF/realizing_potential_energy_efficiency.pdf
} 
revenues grow at a 41\% compound growth rate between 2005 and 2010 (Goldberg, Knoop and Preeble, 2012). Waste reduction is also emerging as a significant opportunity. For example WalMart claims to reduced waste by more than $80 \%$, and in doing so to have returned $\$ 231 \mathrm{~m}$ to the business last year. ${ }^{10}$ Recycling is also an increasingly important business. $70 \%$ of the feedstock to the aluminum industry, for example, is now derived from recycled materials, saving $95 \%$ of the energy required to make new aluminum from bauxite ore, and Waste Management estimates it could generate $\$ 15$ billion of revenue annually if it could effectively separate and resell all the material in the roughly 100 million tons of garbage it collects each year-something that would more than double the size of the company (Hecht, 2014).

\section{Selling to the environmental niche}

A number of firms have been able to build successful businesses by developing highly differentiated offerings targeted specifically to consumers who value environmental performance. While only a relatively small proportion of consumers appear to be willing to pay more today for sustainable products, they are supporting some sizeable businesses. Stonyfield Farm, for example, had 2012 revenues of $\$ 360 \mathrm{~m}$ and revenues at Patagonia, a leader in this space, are estimated to be about $\$ 500 \mathrm{~m}$. Some of the fastest growing restaurant chains are claiming "sustainability" as a key identity. Starbucks is a particularly well known example, but Chipotle had 2012 revenues of almost \$3bn, while Panera Bread had 2012 revenues close to $\$ 2 \mathrm{bn}$. Only $10 \%$ of Clorox's approximate $\$ 5 \mathrm{~b}$ of sales are of "green" products, but they have been providing much of the firm's recent growth (Ofek, 2012).

At an even larger scale, Toyota sells more than 230,000 Priuses every year, making it a roughly $\$ 4.5$ bn business. Whole Foods had 2012 revenues of $\$ 11.7 \mathrm{bn}$, while in the same year the sustainably orientated Triodos Bank had $€ 8.0 \mathrm{bn}$ of assets under management, much of it provided by retail investors committed to the Bank's core mission.

Several opportunities to build entirely new kinds of businesses meeting entirely new needs have also emerged in the environmental space. The "clean tech" sector is both the most well-known

\footnotetext{
${ }^{10} \mathrm{http}: / /$ corporate.walmart.com/global-responsibility/environment-sustainability/zero-waste
} 
and the largest example. Renewable energy is still a relatively small share of the total energy supply, but it is a multi-billion dollar business. Wal-Mart, for example, recently announced that there were planning to source $100 \%$ of their energy needs from renewable sources by 2020 , while Verizon has committed to spending $\$ 100 \mathrm{~m}$ on solar power and fuel cell technologies to power their operations. ${ }^{11}$ Solar and wind have been growing at double digit rates and now provide $12 \%$ of total electric power in the US, with world-wide revenues last year on the order of $\$ 100 \mathrm{bn}$ for each of them. ${ }^{12}$

Actively seeking to reduce consumption by building the so-called "shared economy" is another source of opportunity. For example Avis recently bought Zipcar, the pioneering provider of “wheels when you want them” for \$96m, and Zipcar’s success has drawn in a host of new competitors, including firms such as Car2Go and Mint Cars on demand. Uber, the leading car hailing company, is reported to have revenues of over $\$ 20 \mathrm{~m}$ a week, or more than $\$ 1$ bn a year, while Airbnb, the online room rental service, is expected to reach $\$ 1$ bn in revenues this year. ${ }^{13}$

\section{Building a Business Case in the face of uncertainty:}

Thus in the case of a number of industries - including energy, chemicals, the built environment, transportation and consumer goods -- building a business case to act in the face of the environmental crisis is already relatively straightforward, and this perhaps explains why so many consultants and observers insist that "green is the new gold". In many sectors of the economy and for many firms, however, the business case for investments in sustainability rests much more on their ability to position the firm for advantage in anticipation of the ways in which an increasingly visible environmental crisis is likely to change the competitive context.

Investing in anticipation of major shifts is always risky, but it is often also a powerful source of competitive advantage - or, at the least, a useful means of avoiding competitive disadvantage. In

11

http://www.mckinsey.com/insights/energy_resources_materials/the_disruptive_potential_of_solar_power?cid=R esourceRev-eml-alt-mkq-mck-oth-1404

12 (Pew Charitable Trust "Manufacture, Compete: A Clean Energy Action Plan" http://cleantechnica.com/2013/03/12/biofuel-wind-and-solar-global-market-values-set-to-double-by-2012/).

${ }^{13}$ http://allthingsd.com/20131204/uber-essentially-confirms-revenue-estimates-but-bristles-over-source-ofvalleywag-report/ 
this case, for example, the case for investing to forestall potential brand damage or regulatory costs is likely to become increasingly compelling as consumers become increasingly concerned about sustainability and as regulators respond to their concerns. Investing "ahead of the curve" may also allow firms to create first mover advantage: investing in sustainability before its required, for example, may enable firms to build brand advantage, or to create relationships or assets that will serve them well as the world shifts. Third, leading edge firms often shape the future to their advantage. No one can be sure what will drive the kinds of technical, cultural and political shifts that would make many sustainable business models profitable, but in many cases it seems plausible that private sector action - particularly if it can be coordinated with other stakeholders - may play an important role in making them happen. Lastly, the increases in employee engagement that often emerge as the result of a commitment to sustainability may more than cover the usually minimal costs of making some of these preemptive or exploratory investments.

I develop this argument in more depth using scenario analysis, a tool that was first developed at Shell, the oil major, as a tool for thinking about how a firm might frame strategy in the face of very significant uncertainties, when the common assumption that the future is likely to look like a slightly modified version of today is unlikely to hold (Wilkinson and Kupers, 2014). In these situations it is much more useful to think of the firm as facing several different scenarios, or future worlds, in each of which it might be optimal to adopt a very different strategy, rather than as being faced with a single future for which it must plan.

I explore three sources of uncertainty whose resolution would have a significant effect on the profitability of sustainable action: whether and when mainstream consumers come to value sustainable products and services enough to pay for them; whether and when increasingly acute environmental pressures generate political pressure for additional environmental regulation; and whether and when scientific and technological advances across a range of fields are likely to make responding to environmental issues significantly cheaper.

\section{An emerging consumer movement?}


One of the major uncertainties surrounding the development of sustainable business models is the extent to which consumers will be willing to pay a premium for sustainable products and services. At the moment the evidence on this point is mixed. On the one hand, one study has reported that two-thirds of consumers in six countries say that "as a society, we need to consume a lot less to improve the environment for future generations" $(66 \%)$, and that they feel "a sense of responsibility to purchase products that are good for the environment and society" $(65 \%) .{ }^{14}$ The same study suggested that consumers in developing markets (Brazil, China, India) were more than twice as likely as their counterparts in developed markets (Germany, UK, US) to report purchasing products because of environmental and social benefits, being willing to pay more for sustainable products and encouraging others to buy from companies that are socially and environmentally responsible.

Careful experimental research similarly suggests that in some situations, some consumers will pay a significant premium for some products - although this work is still at a sufficiently early stage that we don't yet have a clear sense for the common factors that are at work across them. For example two large scale field experiments conducted with the apparel manufacturer Gap, suggested that labels with information about a program to reduce water pollution increased sales by $8 \%$ amongst female shoppers, although they apparently had no such effect in outlet stores or on male shoppers (Hainmueller and Hiscox, 2012). Experiments in a major US grocery store chain suggested that sales of the two most popular bulk coffees sold in the store rose by almost 10\% when the coffees were labeled as Fair Trade, (Hainmueller, Hiscox and Sequeira, 2011) and an experiment on eBay suggested that shoppers were willing to pay a $23 \%$ premium for coffee labeled Fair Trade (Hiscox, Broukhim, Litwin, 2013). Similarly several studies of consumers' willingness to pay for "green power" suggest that some consumers are willing to pay a premium for sustainably produced electricity (Bigerna and Paolo, 2011; Borchers etc al., 2007).

On the other hand, "green" products and services remain a niche product in many markets, with many firms reporting that consumers are not willing to pay more for them. For example Wal-

\footnotetext{
${ }^{14} \mathrm{http}$ ://www.sustainablebrands.com/news_and_views/articles/rethinking-consumption-findsconsumers-buying-less-and-betterThe findings are based on an online survey of 6,224 consumers across Brazil, China, India, Germany, the United Kingdom and the United States conducted in September and October 2012.
} 
Mart has not marketed its (extensive) green supply chain initiatives directly to consumers, apparently fearing that the "green" or "sustainable" label may be interpreted as either “expensive" or "lower quality" (Humes, 2011). Whether and when consumer preferences shift in this regard clearly has immediate implications for the profitability of acting sustainably.

\section{Potential Shifts in Political and Regulatory Regimes.}

Similar uncertainties surround whether and when local, state and national governments are likely to react to the threat of environmental degradation. For example some US states have imposed their own "cap and trade" regimes in an attempt to limit the emissions of green-house gases, while others have mandated renewable portfolio standards. Europe has been experimenting with several different forms of carbon regulation, while some countries - including Norway and Australia -- have imposed significant carbon taxes. The Chinese government appears to be attempting to shift its power sector towards a less carbon intensive mix. Attempts to create a global carbon regime have so far been unsuccessful, but if the effects of climate change are as significant as some forecast, they may one day succeed.

Governments across the world are also exploring the possibility of increasing regulatory protection for natural systems such as water, clean air, and a variety of natural habitats, as well as potentially tightening up rules for the disposal of many different kinds of waste, with recent Australian and Chinese activity in this space perhaps the most far reaching example. ${ }^{15}$ Since these kinds of regulations are often viewed as constraints on short term economic growth it is very difficult to predict how they will evolve going forward, but historically significant increases in living standards have been accompanied by political pressure to raise environmental standards, so that accelerating growth in the developing world may well increase the pressure for environmental regulation. Again, appropriate regulation can, of course, completely shift the landscape for private sector action. In the US, for example, investments in wind power have fluctuated significantly in response to the presence or absence of tax credits ${ }^{16}$, while the

\footnotetext{
${ }^{15}$ http://www.economist.com/news/briefing/21583245-china-worlds-worst-polluter-largest-investor-green-energyits-rise-will-have

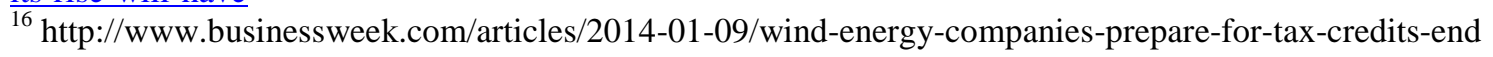


installation of solar power in Germany has been entirely dependent on the provision of generous incentives from the German government. ${ }^{17}$

\section{Technological responses}

Yet another critically important uncertainty is the question of how rapidly technological solutions are likely to emerge in response to the kinds of environmental pressures we are likely to face, since investing preemptively in these kinds of opportunities can often create advantage as costs come down. For example Duke Energy's investments in renewable energy have forced them to explore both the technological challenges and the policy hurdles inherent in moving to distributed power generation, while both IBM and Cisco are investing aggressively in exploring the potential for technology to enable the creation of "Smart Cities". New technologies can rarely be adopted off the shelf, since their successful adoption usually requires the development of detailed knowledge about how they are likely to be used and how they can best be integrated into existing systems.

This issue is particularly salient since humans are almost infinitely resourceful, and it is possible that the next ten years will see major breakthroughs in resource use, in agriculture and in energy production that dramatically lower their costs. For example the cost of both solar and wind power has fallen dramatically over the last ten years - some estimates suggest that the cost of solar power has fallen by over $80 \%,{ }^{18}$ and some experts have predicted that the next few years will see a "resource revolution" in which investments of more than \$1 trillion may lead to \$3-4 trillion of potential efficiency gains. ${ }^{19}$ Similarly new approaches to the generation of nuclear power may significantly reduce costs, waste generation and the threat of nuclear proliferation (Sahlman et al, 2012), while in Singapore introducing "smart" transportation systems may cut the number of vehicles on the road by over $60 \%$ while improving levels of service. ${ }^{20}$ Investing in

\footnotetext{
${ }^{17}$ Policymaker's Guide to Feed-in Tariff Policies, U.S. National Renewable Energy Lab, 2010, www.nrel.gov/docs/fy10osti/44849.pdf

${ }^{18} \mathrm{http}: / /$ cleantechnica.com/2013/05/06/solar-pv-module-prices-have-fallen-80-since-2008-wind-turbines-29/

${ }_{20}^{19} \mathrm{http}: / / \mathrm{www} . \mathrm{mckinsey} . \mathrm{com} /$ features/resource_revolution

http://app.mot.gov.sg/page_land.aspx?p=/Land_Transport/Sustainable_Development/Promoting_Sustainable_Trans port.aspx\&AspxAutoDetectCookieSupport=1
} 
advance of these kinds of trends can allow the firm to develop the kind of on the ground experience, customer knowledge and regulatory relationships that can allow them to take advantage of technological change as it occurs.

Scenario Analysis: Exploring the interaction between these trends

Following Peter Schwartz (1996), one can use these uncertainties to define a 2x2 grid defining four possible future worlds. I assume that the possibility that consumers will be willing to pay for products and services that prevent or mitigate environmental harm is so closely correlated with the possibility that there will be increasing political pressure for increased regulation that the two are effectively equivalent. This is clearly an enormous simplification, and if one was conducting this analysis for a single industry, or for a single geography one could be much more precise but at this very broad level of analysis it's not an unreasonable first cut. Figure (4) shows the results of mapping this possibility against the possibility of significant technological change.

Figure 4 about here: Basic scenario analysis

Any such mapping is necessarily a simplification of a hugely complex underlying reality. This particular map, for example, doesn't explicitly focus on the question of how rapidly environmental degradation is likely to occur going forward, and here I thus make the implicit assumption that from a business perspective the key issue is not how rapidly the environmental crisis is likely to unfold but whether and how such degradation will feed through into consumer response or political action. Despite its simplicity, however, this map immediately highlights a number of critically important strategic and organizational dynamics.

Between them, the two uncertainties define four possible scenarios: "Business as usual", "Green goes main-stream", "Demand driven opportunity" and "Supply driven opportunity." "Business as usual" is a world in which neither consumer demand nor regulatory pressure leads to any significant increase in the demand for sustainable products or services, and in which implementing sustainable solutions remains relatively expensive. Notice that it could still be a world in which there was very substantial environmental degradation - in this world, however, 
such degradation does not lead to any pressure for action. This is the world that most firms experience at present, and it appears to be the future that is taken for granted by many business people. For example, Exxon Mobil recently released a report asserting that the firm does not believe that there is a significant risk that any of their current reserves will become "stranded", or valueless, as a result of future changes to regulatory policy. ${ }^{21}$

Even those business people who do not believe that "business as usual" is the most likely future often act as if it were - as decades of organizational research have taught us, assumptions about how the world works and how it is likely to evolve are often deeply embedded in the deep structure of an organization - in its identity, in its information processing routines, and in its organizational capabilities (Nelson and Winter, 1982; Hannan and Freeman, 1989; Tushman and O'Reilly, 1997). The identity and mental models of an organization often evolve only very slowly (MA Glynn in this book; Kaplan, 2008; Tripsas and Gavetti, 2000).

"Green goes Mainstream" is a world in which accelerating technological change in combination with robust demand driven either by consumer preference or political pressure has opened up large markets for sustainable products and services. For those parts of the solar energy and wind power industry with strong political support and for those businesses such as Zipcar or Uber that already sell to sustainably orientated consumers and for whom the technologies necessary to support their business are already in place, this world is already a reality, but for many firms it remains only a possibility.

In "Demand Driven Opportunity", the technological progress necessary to develop new products is slow in coming and/or costly, but consumer or voter concern has led to an increasing demand for green products and/or for policies the penalize conventional offerings. Firms such as Patagonia and Seventh Generation that sell more expensive products to those consumers who currently care about sustainability are already experiencing this world, but to date these kinds of products remain a relatively small share of the market.

\footnotetext{
${ }^{21}$ http://cdn.exxonmobil.com/ /media/Files/Other/2014/Report\%20-\%20Energy\%20and\%20Carbon\%20\%20Managing\%20the\%20Risks.pdf
} 
"Supply Driven Opportunity", is a world in which significant technical change has opened up opportunities, but neither consumers nor politicians are willing to allocate resources to pay more for sustainable products. The very large efforts focused on reducing energy demand are already experiencing this world - acting sustainably is economically viable even in the absence of consumer demand, and many observers believe that acceleration in raw material prices of all kinds will drive significant activity to this space going forward.

Mapping these examples to industries highlights the way in which the current case for sustainability differs enormously across the economy, with the major opportunities currently occurring in energy, buildings, water, agriculture and consumer goods. In these cases the uncertainties I have mapped are increasingly no longer uncertainties - firms can be sure that technological progress will occur, or that consumer or regulatory demand will enable them to offer a more highly priced product. But framing the strategic space in this way also focuses attention on the fact that for many industries, the case for becoming more sustainable rests on the assumptions one makes about how these uncertainties are likely to play out.

In many industries raw materials and energy are a relatively small percentage of value added, and there is as yet only nascent consumer and political pressure to become more sustainable. One way to approach the development of sustainable business models in these contexts is to simply insist that the world is changing, and that becoming more sustainable is a far sighted anticipatory response. But as the discussion above suggests, we cannot be certain how the world is likely to evolve. It might prove to be the case, for example, that technological change triggers such significant improvements in resource productivity, and/or such dramatic reductions in the costs of carbon free energy, that we can arrest or reverse the environmental decline and resource productivity that might otherwise occur. Similarly environmental degradation could continue to accelerate, but economic pressure may make mainstream consumers very reluctant to pay for green products and there may never be sufficient political will to impose appropriate regulation. Even if one believes that both trends are inevitable, there can be significant disagreement about the pace of change. It is much easier to make a business case if one is reasonably certainly that major regulation is likely to be imposed next year than if one believes it is likely, but not for another twenty years. This kind of uncertainty is a constant feature of disruptive or discontinuous 
change, but it is not, in itself, a reason to do nothing. Nokia, for example, lost its phone business because of its inability to make a compelling case to make the investments necessary to compete with Apple in the smart phone business, while Corning survived the dot-com crash because it had invested in the technology necessarily to make large displays many years in advance of their becoming commercially viable.

This uncertainty has very significant implications for the leadership of sustainable change. In the first place, it highlights the importance of distinguishing between models that are profitable now, given today's prices and technology, and models that represent strategic bets against possible future states of the world. Persuading a firm to make investments that are likely to immediately profitable, while by no means always easy, presents a fundamentally different kind of strategic and organizational challenge from persuading firms to develop models whose success is contingent on some uncertain future state. In the second place, it focuses attention on the contingent nature of plausible sustainable business models. Their profitability in any particular context is going to be dependent on the rate at which the relevant uncertainties resolve themselves and their salience for the nature of the business. In any particular industry, the potential profitability of sustainable business models will be dependent on how much pressure these forces can exert, and on how rapidly they resolve.

Consider, for example, Unilever's move to introduce "sustainable tea". In 2007 Unilever became the first major tea company to commit to sustainable sourcing on a large scale. Unilever's tea business is substantial - Unilever sells roughly $€ 3.5 \mathrm{bn}$ worth of tea, approximately $30 \%$ of the world's market for branded tea, and buys approximately $12 \%$ of the world's supply of black tea. The firm is committed to sourcing $100 \%$ of its tea sustainably by 2020 , and in partnership with the Rainforest Alliance has developed an auditable standard. As of February 2014, 39\% of Unilever's tea purchases were sourced from Rainforest Alliance certified farms. ${ }^{22}$

Estimating the economic returns to this effort is complicated by the fact that it is impossible to know what would have happened to Unilever's share of market without the adoption of Rainforest Alliance certification, but those numbers that are available suggest that by 2011 the

\footnotetext{
${ }^{22}$ http://www.unilever.com/sustainable-living/sustainablesourcing/tea/ Accessed 2/1/2014
} 
effort had roughly broken even. Moving to certified tea required training farmers - between 2007 and the end of 2012, for example, 450,000 farmers had been trained to Rainforest Alliance standards - and also meant paying a small premium for certified tea. However in some markets the introduction of certified tea was associated with significant market share gains, at least in the short term. For example in the UK, the introduction of Rainforest Alliance certified tea was associated with a share gain of $1.8 \%$ (Henderson, 2011). These introductions were not costless for example in the UK, Unilever spent the entire $€ 12 \mathrm{~m}$ marketing budget on launching the new product - but given the difficulty of making share gains in such a hotly contested space these results are suggestive. The move to sustainable sourcing also generated economic gains for the farmers involved, as in many cases yields increased significantly and costs fell.

Has this strategy been successful? It has since been widely imitated by Unilever's competitors, with many of the world's largest tea brands announcing a commitment to sustainability. Such rapid imitation would suggest that the idea has gained some traction amongst consumers, and there is some evidence that Unilever's commitment to sustainability has significantly increased employment commitment and engagement. ${ }^{23}$ Moreover there is no evidence that it has harmed the brand, and some that it may even have increased brand equity.

But to think about it this way is to miss the point. Thinking about Unilever's strategy in the context of the scenario grid of figure 4 suggests that it is better thought of as an experiment or as a well-designed strategic option. If the world does not change significantly - if the next five years see the "business as usual" scenario playing out - then Unilever has lost nothing. But should the world change - if, for example, consumer preferences switch aggressively towards sustainable brands -- then Unilever may have established a first mover position in consumers' minds that could be tremendously valuable. Less plausibly but still possibly, should climate change indeed have a negative effect on the productivity of tea plantations, Unilever's moves may have given it an advantage in accessing worldwide tea supplies. And of course if both should happen - should the tea industry move to the "green goes main-stream" future - then in retrospect Unilever's investment will come to be seen as a brilliant strategic move.

\footnotetext{
${ }^{23} \mathrm{http} / / / \mathrm{www}$. unilever.com/sustainable-living/betterlivelihoods/developing-and-engaging-our-people/
} 
Another intriguing example is that of the Nissan Leaf. The Leaf - an all-electric five passenger compact car - was launched in December 2010. By the end of June 2013 the firm had cumulative sales of roughly 70,000 units (Nissan 2013 Annual report), and installed capacity of 250,000 units/year ${ }^{24}$. The firm claimed that the Leaf was a profitable product ${ }^{25}$ but with estimates of Nissan's commitment to the car running as high as €4bn, and cumulative sales probably no greater than $\$ 2.2 \mathrm{bn}$, it seems hard to argue that - at least so far - the Leaf has achieved a positive rate of return on its investment. ${ }^{26}$

But the Leaf, too, can be viewed as a strategic option against an uncertain future. Carlos Ghosn, Nissan's CEO, defends the Leaf as a long term investment, and as an "asset to the brand." ${ }^{27} \mathrm{He}$ hopes to use it enter the Chinese market, and he also believes that the company's head start in electric vehicle battery technology may give it a long term advantage (Burgelman and Schifrin, 2011). As in the case of Unilever's tea business, in the "business as usual" scenario it's hard to see the Leaf as a huge success. But Nissan can certainly afford the investment -- in 2012, Nissan's revenues were \$94bn, and net income was over \$5bn (Nissan AR 2012) - and again, should consumer preferences shift towards sustainability, or should the political climate shift to support widespread carbon regulation, Nissan's first mover position may give it a very significant advantage in a "demand driven opportunity" world.

A number of other major consumer orientated companies similarly appear to be preparing for a world in which consumers increasingly value sustainable products. For example it is probably not the case that Chipotle's recent remarkable growth has been driven by its commitment to "Food with Integrity", since in a 2007 interview the CEO of Chipotle estimated that only about $5 \%$ of his consumers knew about the campaign and the company conducts only minimal advertising. ${ }^{28}$ But the firm's positioning both give it an edge with those consumers who do value

\footnotetext{
${ }^{24}$ http://insideevs.com/nissan-leaf-production-starts-at-3rd-assembly-plant-in-sunderland-uk-factory-video/ Accessed 2/1/2014

${ }^{25}$ http://www.sustainablebusiness.com/index.cfm/go/news.display/id/25362 Accessed 2/1/2014

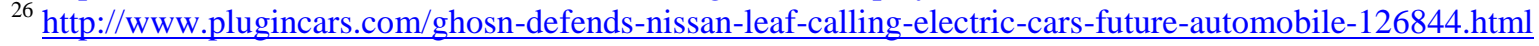
accessed 2/1/2014

${ }^{27}$ http://www.plugincars.com/ghosn-defends-nissan-leaf-calling-electric-cars-future-automobile-126844.html accessed $2 / 1 / 2014$

${ }^{28}$ http://www.businessweek.com/stories/2007-02-16/chipotle-fast-food-with-integritybusinessweek-businessnews-stock-market-and-financial-advice accessed 2/1/2014
} 
sustainable agriculture and means that should consumer tastes shift the company will be well positioned to meet them.

The renewable energy strategies currently being pursued by many of the large energy suppliers can similarly be best understood as strategic hedges, placed against the possibility that carbon will be regulated or taxed in the foreseeable future, and/or that the price of conventional energy will rise dramatically. For example the economics of Duke Energy's plan to build a nuclear reactor look only marginally profitable given today's energy prices and regulatory regime, but would look a great deal better should either shift (Vietor and Reinhardt, 2014), while BP's $\$ 2.9$ bn in range of renewable technologies including wind, solar and biofuels, ${ }^{29}$ almost certainly has a similar strategic rationale.

Implications for leading sustainable change

This framing has a number of important implications for the leadership of sustainable change. In the first place it suggests that developing a deep understanding of key uncertainties - and incorporating them directly into the firm's strategic thinking - may be critically important to building an accurate and persuasive business case for sustainability. In many contexts it is a mistake to blindly insist that acting sustainably is simply "the right thing to do" or that is always likely to be profitable. Some of the discussion around shared value, for example, can be construed as suggesting that the set of actions that simultaneously make a difference in the world and create value for the firm is clearly delineated. In reality, however, this boundary is both fuzzy and constantly changing - and this has important implications both for how the strategic process should be led and for how organizational efforts designed to improve the sustainability of the firm should be managed.

Managing the strategy process

\footnotetext{
${ }^{29}$ http://www.bp.com/sectiongenericarticle.do?categoryld=9030041\& contentld=7055175 Accessed 2/1/2014
} 
In established businesses dominated by incremental change, strategic planning is often difficult to distinguish from budgeting, and is largely a matter of planning incremental extensions to the current business. Indeed in many firms the immediate needs of the firm's largest customers dominate the strategic agenda, making it very difficult to invest in anything significant different (Christensen, 1997). The fact that the business case for sustainability is - for many sectors and firms - likely to be dependent on the recognition of the uncertainties facing the world and the potential advantage that may be realized by anticipating them suggests that one of the most important tasks for leaders trying to driven their organization towards sustainability is the development of a strategic process that incorporates the time and expertise necessary to do the kind of uncertainty driven strategic framing I have outlined above. Such a process, for example, would invest heavily in understanding the nature of the most salient uncertainties facing the business, would carefully tracks them over time (Wilkinson and Kupers, 2014), and would focus attention on those investments that are likely to be "robust", in that they are worth making in a range of possible futures.

Developing such a process is also likely to have a number of important organizational benefits. Strategic discontinuities must be coupled with organizational discontinuities if they are to be navigated successfully. Large, successful firms often react to them first with denial - "it's not happening" - then with skepticism “even it does happen we won't be able to make any money' and then with incompetence and inertia, as old identities, structures and processes make the execution of new strategies difficult (Tushman and Romanelli, 1985; Hannan and Freeman, 1989).

Effective strategic framing can be a powerful tool to help overcome these kinds of barriers. In the first place, new frames can help to confront denial. The reluctance to admit the possibility that the world is fundamentally changing is deeply rooted in both individual cognition and in the dynamics of firm identity. In this context, simply asserting that the world is changing and expecting the organization to shift is unlikely to be successful. But using a tool like scenario analysis - one that moves the debate away from the question of "is global warming real?" to "is there a real possibility that an increased public perception that global warming is real may lead to increased regulation of global warming gases?" can be enormously helpful in reframing 
perceptions. Figure 5, for example, shows the probabilities that two groups of executives placed on the long term uncertainties of figure 4 in the context of a discussion of the energy supply business, on the one hand, and in the context of the consumer goods industry, on the other. ${ }^{30}$

Figure 5 about here

In both cases the "business as usual" scenario - no major shift in the technological opportunity set and no major shift in either consumer demands or the regulatory context - is the most likely scenario. But in both cases the odds of its coming to pass - if one believes these executives -- is less than 50\%. My experience has been that if this recognition - that by their own reckoning the odds of the "business as usual" scenario continuing into the indefinite future are less than 50/50 - changes the conversation amongst a group in significant ways. Indeed in some cases I have seen it support a major shift in orientation - away from "it isn't going to happen" to "it might happen" - and - most importantly -- to the idea that assuming that there is no real chance that sustainable business models will be important is a mistake. This kind of analysis can be also be organizationally helpful is that it immediately highlights the business case for investing in "experiments", and for developing the organizational capabilities that will be required to make these experiments a success.

Another benefit of thinking through the potential for sustainable business models from this perspective is that it also focuses attention on the factors that are likely to resolve the uncertainties that are central to any decision, and most importantly on the degree to which firms themselves can affect these uncertainties. For example, Unilever's decision to put its entire tea business on a sustainable footing has been followed by similar announcements from all of its major competitors. What might thus have been a competitive disadvantage for the firm has thus been transformed into table stakes - and possibly into an advantage, since Unilever has a very significant head start in greening its supply chain. While one cannot be sure that Unilever's behavior has caused this shift, it certainly seems within the realm of possibility. Similarly Nissan's investment in electric vehicles has been accompanied by a commitment to sell the technology that it develops as a result to the rest of the industry, thus significantly reducing the

\footnotetext{
${ }^{30}$ Both figures are composites derived from teaching and consulting to a large number of global executives.
} 
costs of other firms also introducing electric vehicles - and potentially accelerating the adoption of the infrastructure needed to support them. The private sector investments in clean energy that have played a huge role in driving down the cost of both wind and solar energy - some observers now believe that solar energy may be cost competitive with fossil fuel based energy by 2020 in most applications - have similarly changed both the political climate surrounding carbon regulation.

More broadly, it seems plausible that many of the shifts in consumer preferences and/or in the political environment that are likely to make the widespread deployment of profitable sustainable models profitable are unlikely to happen without coordinated action at either the level of the industry or the state. Building the basis for a sustained conversation about sustainable business models thus has the potential to support the firm's engagement in these broader networks and levels of action. For example Nike has been central to the apparel industry's effort to improve both environmental and labor standards, while HP and IBM appear to have played similarly critical roles within the IT industry. There is some evidence that these kinds of efforts can play a crucial role in complementing local state based regulation (Locke, 2013). Thinking about strategic efforts within this kind of contingent framework may thus be a means for engaging the organization in the kinds of long term, multiple player based effort that is almost certainly critical to long term sustainable change.

\section{Organizational implications}

Thinking of many sustainability orientated investments as hedges against risk or as strategic bets against future states of the world also highlights the fact that they may need to be managed quite differently from investments designed to pay off in the near future, in ways that are orientated towards the support of flexibility and innovation. Shifts in strategy must be coupled with shifts in organizational architectures. This is a theme that is taken up extensively in the other chapters of this volume, but the scenario based perspective provides a particularly useful lens through which one can understand quite how important this is likely to be and why it is likely to be particularly difficult because it makes explicit the fact that there is no guarantee that these efforts will be successful. 
As a long literature has suggested, the organizational structures best suited to exploit the existing business are quite distinct from those required to explore new possibilities (March, 1991; Henderson and Clark, 1990; Tushman and O’Reilly, 1997; Tushman, O’Reilly, Harreld, Ancona, Edmondson, this book)). Running the existing business well requires well developed skills in operational excellence and the ability to execute rapidly and effectively, while building entirely new businesses often requires abandoning existing routines and procedures in favor of new ways of operating that support creativity, flexibility and the ability to fail. These two modes typically require quite different organizational structures, quite different incentive structures and quite different time frames and formal metrics.

If it is indeed the case that in many firms' environmental investments are strategic bets against possible futures, managing them will require holding the tension between these two very distinct modes of organizing. Opportunities within the "business as usual" quadrant may challenge the organization, but they have the great advantage of being at least no minimally profitable according to the firm's established metrics. Opportunities in the other three quadrants are - by definition - only likely to be significant sources of financial return in the potentially quite distant future and in some - very uncertain - states of the world. They are exploratory by their very nature, and investing effectively in them is likely to require both the implementation of local mechanisms that ensure they are managed to allow for creativity and flexibility and the development of the capability at the most senior level of the firm to manage two very different kinds of project simultaneously. In this context effective leadership must be "ambidextrous" able to support the evolution of the firm's identity and organization in a way that both honors the firm's pasts and invests against its probable future. This is the task explored in the subsequent chapters of this volume.

\section{$\underline{\text { Conclusion }}$}

In this chapter I have argued that making the business case for sustainable environmental change is both more complex and more interesting than is generally assumed. I have argued that as many 
observers have suggested, in some industries and for some firms the benefits of environmental action can be directly internalized today, focusing particularly on the benefits of using raw materials more efficiently, securing supply, preventing brand damage, selling to the sustainable niche and building entirely new businesses. But I have further suggested that for many firms, the case for sustainable change is better understood as a strategic bet against a number of possible future states. I have suggested that if this is the case it not only explains why cross sectional studies of the relationship between environmental action and financial returns have yielded such mixed results, but also has important implications for the ways in which one should think about leading and learning how to execute sustainable change 


\section{$\underline{\text { References }}$}

Bigerna, Simona and Polinori, Paolo (2011): Italian consumers' willingness to pay for renewable energy sources. Working paper, MPRA http://mpra.ub.uni-muenchen.de/34408/

Borchers, Allison, Duke, Joshua and Parsons, George. "Does willingness to pay for green energy differ by source?” Energy Policy Volume 35, Issue 6, 2007 pp3327-3334

Tim Bresnahan, Shane Greenstein and Rebecca Henderson: "Schumpeterian Competition and Diseconomies of Scope: Illustrations from the History of Microsoft and IBM".Chapter 4, pages 203-276 in The Rate and Direction of Inventive activity Revisited, Ed J. Lerner \& Scott Stern, NBER conference volume, University of Chicago Press, 2012, Chicago and London.

Burgelman, Robert and Debra Schifrin, “Nissan's Electric Vehicle Strategy in 2011”, June 2011. HBS Case No. SM189

Christensen, Clayton, The Innovator's Dilemma, Harvard Business School Press, 1997, Boston MA.

Hiscox, Michael, Broukhim, Michael and Claire Litwin: "The premium for fair trade: new evidence from a field experiment using ebay auctions." March 2011 http://papers.ssrn.com/sol3/papers.cfm?abstract_id=1811783

Eccles, Robert G., Ioannis Ioannou, and George Serafeim. "The Impact of Corporate Sustainability on Organizational Processes and Performance." Harvard Business School Working Paper, No. 12-035, November 2011. (Revised May 2012, July 2013.)

Eccles, Robert G, George Serafeim and Tiffany Clay: KKR: Leverage Sustainability. HBS Case No. 112032, March 2012

Esty, Daniel and Andrew Winston. Green to Gold: How Smart Companies Use Environmental Strategy to Innovate, Create Value, and Build Competitive Advantage Wiley 2006

Goldberg, Ray, Carin-Isabel Knoop, Matthew Preble, "Jain Irrigation Systems Limited: Inclusive Growth for India's Farmers”. HBS Case 912403, February 2012

Hainmueller, Jen, M Hiscox and S Sequeira "Consumer Demand for the Fair Trade Label: Evidence from a Field Experiment" Review of Economics and Statistics, (Forthcoming 2014).

Hainmueller, Jens "The Socially Conscious Consumer? Field Experimental Tests of Consumer Support for Fair Labor Standards" (with M. Hiscox). May 2012 Stanford University, Working paper

Hannen, M.T. and Freeman, J.H.: Organizational Ecology, Harvard University Press, Cambridge MA., 1989. 
Hansen, Morten T., Herminia Ibarra, and Urs Peyer. "The Best-Performing CEOs in the World." Harvard Business Review, January-February 2010.

Heck, Stefan, Matt Rogers and Paul Carroll. Resource Revolution: How to Capture the Biggest Business Opportunity in a Century New Harvest, 2014

Henderson, R.M, and K.B.Clark.: "Architectural Innovation: The Reconfiguration of Existing Product Technologies and the Failure of Established Firms." Administrative Science Quarterly, 35 (1990) 9-30.

Henderson, Rebecca "Sustainable tea at Unilever" HBS Case 9-712-438, December 2011

Hoffman, Andrew, From Heresy to Dogma: An Institutional History of Corporate

Environmentalism. Stanford University Press, 2002

Humes, Edward Force of Nature: The unlikely story of Wal-Mart's green revolution. Harper Business, 2011.

Jorgenson, Dale, Richard Goettle, Mun Ho, Peter Wilcoxen. Double Dividend: Environmental Taxes and Fiscal Reform in the United States, MIT Press, 2013

Kaplan, Sarah: Framing Contests: Making Strategy Under Uncertainty; Organization Science; 2008

Locke, Richard M. The Promise and Limits of Private Power Promoting Labor Standards in a Global Economy, Cambridge University Press, May 2013

March, James G.: "Exploration and Exploitation in Organizational Learning: Organizational Science, February 1991.

Margolis, Joshua D., and James P. Walsh. "Misery Loves Companies: Rethinking Social Initiatives by Business." Administrative Science Quarterly 48 (June 2003): 268-305.

McKinsey Global Institute. "Resource revolution: meeting the world's energy, food and water needs" November 2011

Nelson,R. and Winter, S. An Evolutionary Theory of Economic Change, Cambridge, Massachusetts, Harvard University Press, 1982.

Ofek, Elie and Lauren Barley "The Chlorox Company: Leveraging Green for Growth". Harvard Business School Press, Case study, 2012

Porter, Michael and Mark Kramer, "Creating Shared Value" Harvard Business Review January 2011 
Reinhardt, Forest; Ramon Casadesus-Masanell, Frederick Nelleman, "Maersk Line \& the Future of Container Shipping", HBS Case No. 712449, June 2012

Sahlman, W, Nanda, R, Lassiter J and J McQuade “Terrapower" HBS case 9-813-108, December 2012

Schwartz, Peter. The Art of the Long View: Planning for the Future in an Uncertain World Doubleday 1996

Stavins, Robert. "The Problem of the Commons: Still Unsettled after 100 Years" American Economic Review, February 2011, 81-108

Stern, Nicholas, "The economics of climate change" American Economic review Vol. 98, No. 2, May, 2008

Toffel, Michael W., and Jodi L. Short. "Coming Clean and Cleaning Up: Does Voluntary SelfReporting Indicate Effective Self-Policing." Journal of Law \& Economics 54, no. 3 (August 2011): 609-649.

Tripsas, Mary and Giovanni Gavetti "Capabilities, Cognition and Inertia: Evidence from Digital Imaging” Strategic Management Journal, Fall 2000, Vol 21, 1147-1161.

Tushman, Michael and O'Reilly, C. Winning through Innovation, Boston, MA, Harvard Business School Press, 1997

Tushman, M. L., \& Romanelli, E. 1985. Organizational Evolution: A Metamorphosis Model of Convergence and Reorientation, Research in Organizational Behavior, Vol. 7: 171-222. Greenwich, CT: JAI Press.

Vietor, Richard and Forest Reinhardt, "Duke Energy and the Nuclear Renaissance”, HBS Case No 712002, February 2014.

Wilkinson, Angela and Roland Kupers, The Essence of Scenarios: Learning from the Shell Experience Amsterdam University Press, 2014

Winston, Andrew, The Big Pivot: Radically Practical Strategies for a Hotter, Scarcer, and More Open World 


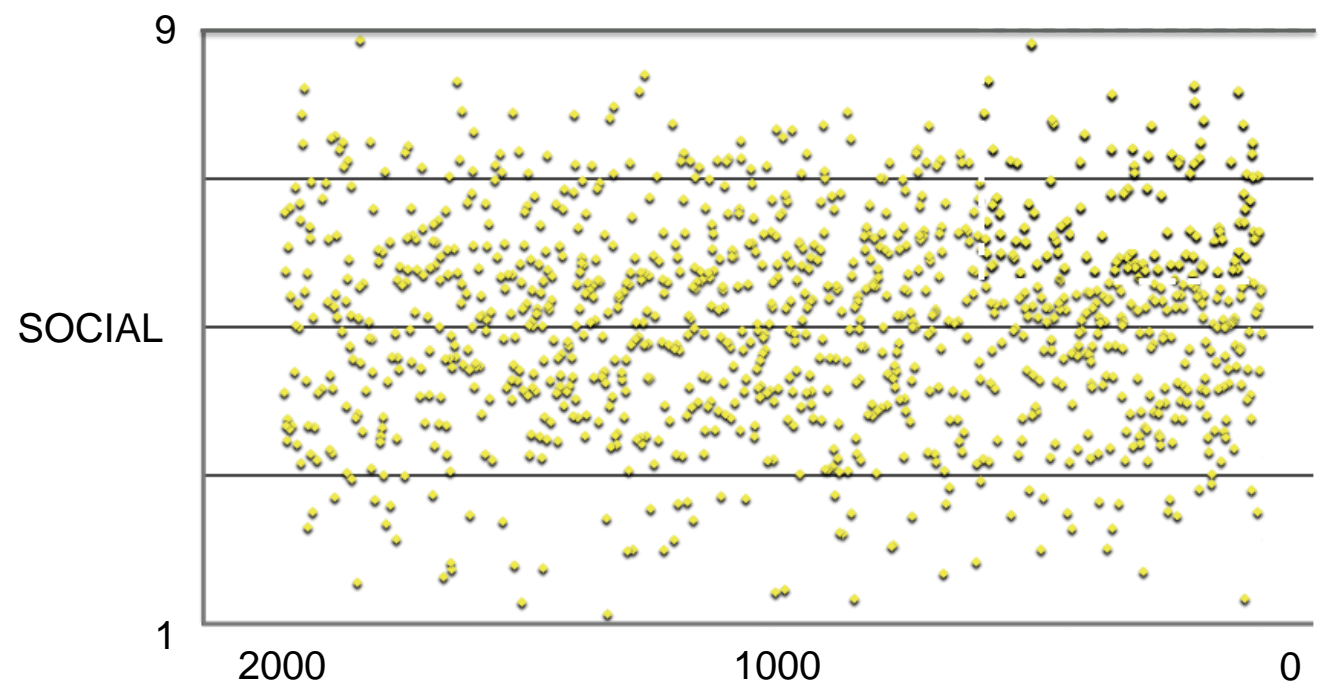

FINANCIAL

Reprinted with permission from "The Best-Performing CEOs in the World" by Morten T. Hansen, Herminia Ibarra, and Urs Peyer. Harvard Business Review, January 2013. Copyright @ 2013 by Harvard Business Publishing; all rights reserved.

Figure 1: Long-term financial performance of $~ 1,100$ CEOs against their companies' social and environmental performance for their last two years in office. 
Figure 2: The McKinsey Cost Curve

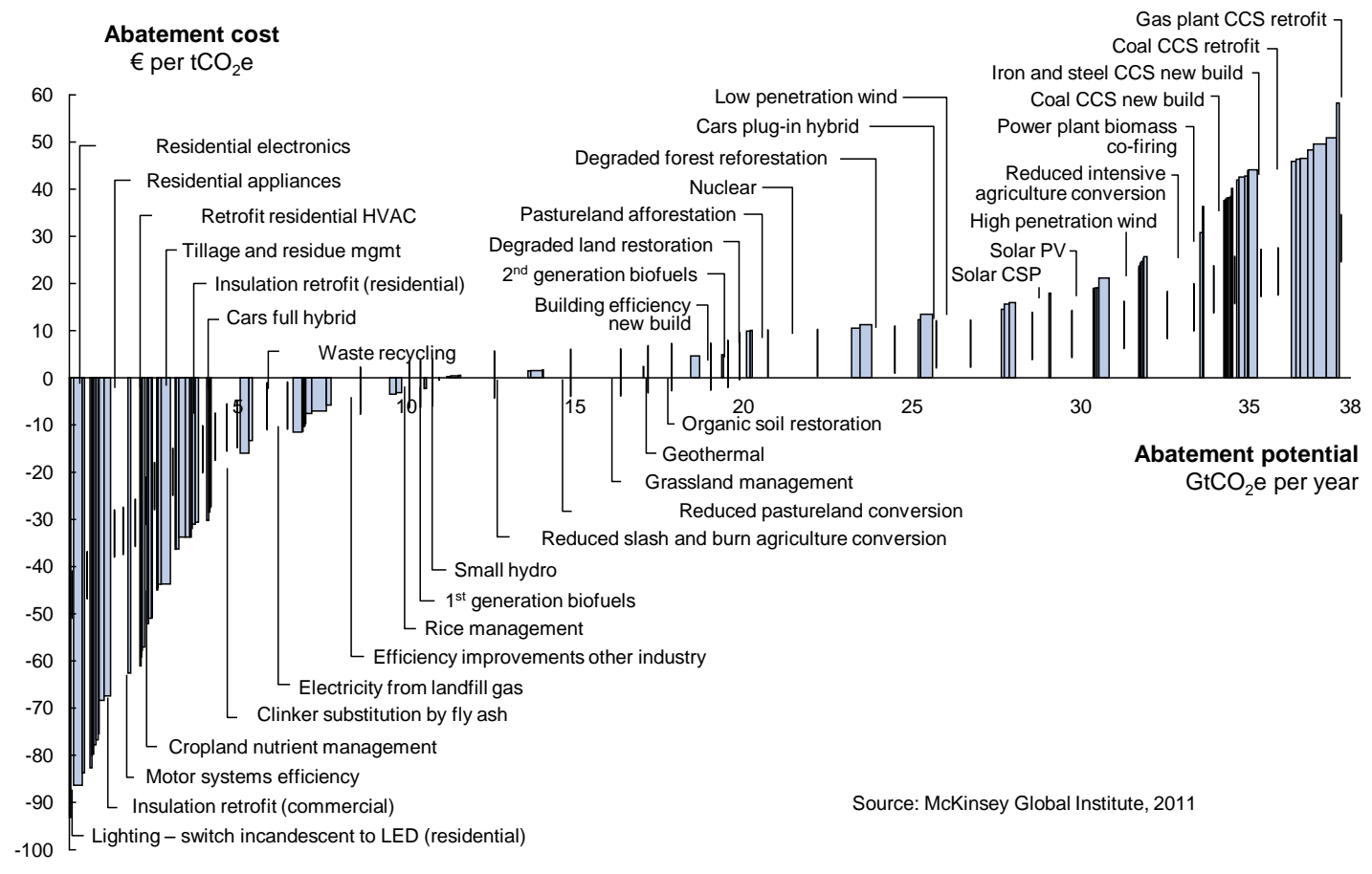




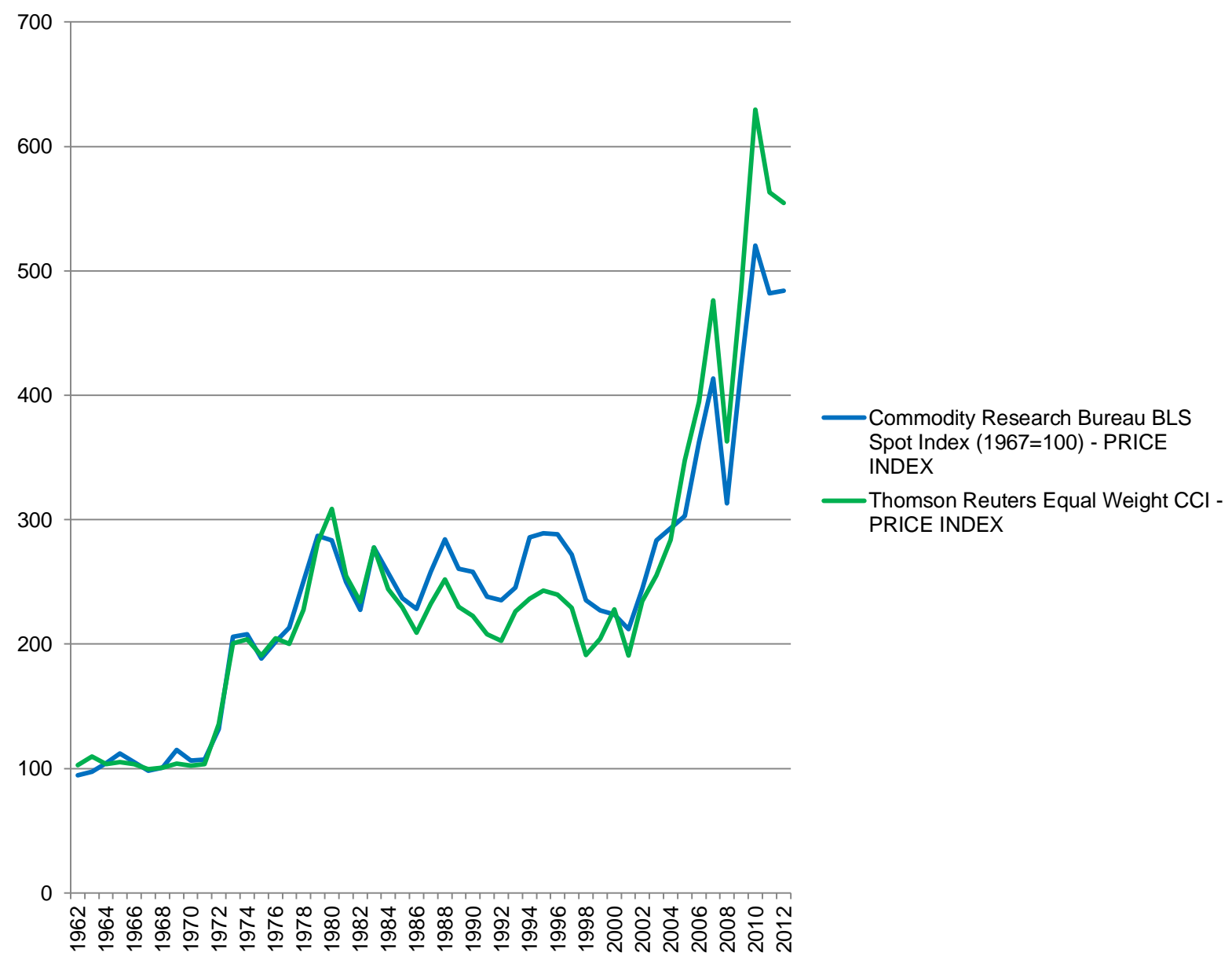

Source: Thomson Datastream

Figure 3: The evolution of commodity prices 1962-2012 
Political pressure

and/or consumer sentiment

creates strong demand for "sustainable" products/services

\section{"Demand driven opportunity"}

Technological advance is slow:

Acting sustainably expensive

"Business as usual"

Minimal demand for sustainable products/services
"Green goes mainstream"

Technological advance is rapid: Acting sustainably is cost effective

"Supply driven opportunity"

Figure 4: One possible scenario grid 


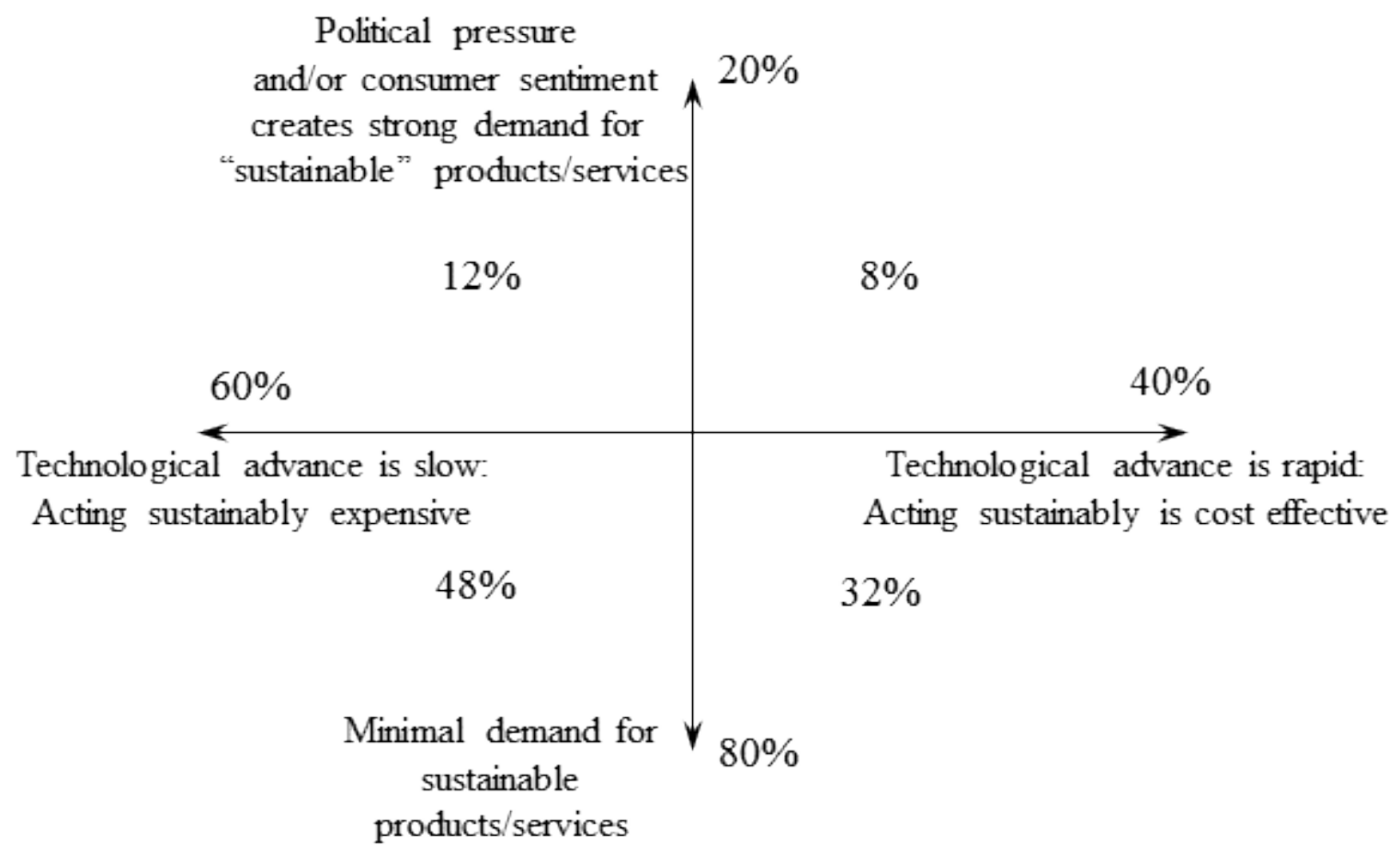

Figure 5A: Estimated uncertainties in the energy supply industry

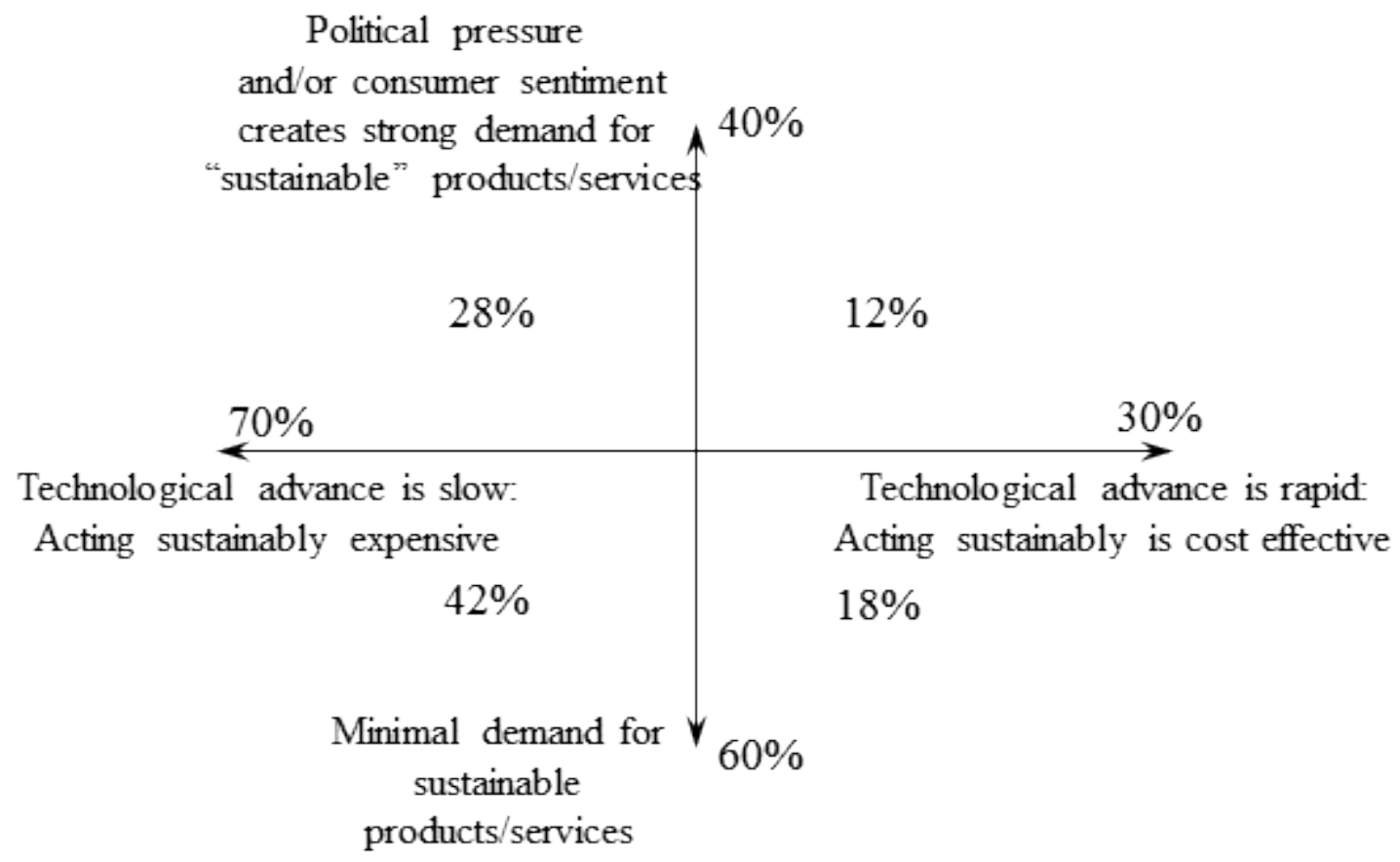

Figure 5B: Estimated uncertainties in a consumer goods industry 